\title{
Bioanalytical Method to Measure Fluazuron in Bovine Plasma and its Application in Pharmacokinetic Studies
}

\author{
Ferreira, T. P.; Lima, I. P.; Magalhães, V. S.; Avelar, B. R.; Oliveira, G. F.; \\ Scott, F. B.; Cid, Y. P.*
}

Rev. Virtual Quim., 2019, 11 (3), 1067-1079. Data de publicação na Web: 1 de julho de 2019

http://rvq.sbq.org.br

\section{Método Bioanalítico para o Fluazuron em Plasma Bovino e Sua Aplicação em Estudos de Farmacocinética}

Resumo: Fluazuron é um regulador de crescimento de insetos pertencente à classe da benzofeniluréia que é comercializado para o controle do carrapato bovino. Embora os reguladores de crescimento sejam uma classe amplamente estudada, o número de artigos descrevendo métodos analíticos para determinar o fluazuron em amostras de plasma animal é reduzido. Para avaliar a característica farmacocinética do fluazuron em bovinos, foi avaliado e validado um método CL-UV. As condições experimentais foram otimizadas pelo estudo comparativo de três métodos de extração: ELL, EFS e DMFS. A separação cromatográfica foi realizada na coluna Kromasil C18, com fase móvel de acetonitrila: água (80:20, v/v) na vazão de $1,0 \mathrm{~mL} / \mathrm{min}-1$. O método foi validado de acordo com as exigências da ANVISA dentro da faixa de 20 a $150 \mathrm{ng} \mathrm{mL}-1(\mathrm{r}>$ $0,99)$. O LD e LIQ para o fluazuron foram 10 e $20 \mathrm{ng} \mathrm{mL}^{-1}$ no plasma. A precisão e exatidão inter / intra-ensaio foram $\leq 9,48$ $\%$ (CV) e $\leq 10,3 \%$ (EPR), respectivamente. Como resultado, foram obtidos parâmetros farmacocinéticos de $C_{\max }(74,4 \pm 3,52$ $\left.\mathrm{ng} \mathrm{mL}^{-1}\right), \mathrm{AUC}_{0-\mathrm{t}}\left(1007 \pm 33,5 \mathrm{ng}^{*} \mathrm{~d} \mathrm{~mL}^{-1}\right)$ e $\mathrm{t}_{1 / 2}(14,6 \pm 2,97 \mathrm{~d})$ para fluazuron após administração tópica em bovinos. O método bioanalítico foi adequado para a aplicação nos estudos de farmacocinética, uma vez que os valores de LIQ para o fluazuron permitiram que a quantificação atingisse a $\mathrm{AUC}_{0-\mathrm{t}}$ superior a $80 \%$ da $\mathrm{AUC}_{0-\infty}$.

Palavras-chave: Benzoilfenilureia; método bioanalítico; preparação de amostras; farmacocinética.

\begin{abstract}
Fluazuron is an insect growth regulator belonging to the benzoylphenylurea class that is marketed for the control of cattle ticks. Although growth regulators are a widely studied class, the number of papers describing analytical methods for determining fluazuron in plasma samples is reduced. To evaluate the pharmacokinetic characteristics of fluazuron in cattle, a LC-UV method was evaluated and validated. The experimental conditions were optimized by comparative study of three extraction methods: LLE, SPE and MSPD. The chromatographic separation was achieved in a Kromasil C18 column, with mobile phase of acetonitrile: water $(80: 20, \mathrm{v} / \mathrm{v})$ at flow rate of $1.0 \mathrm{~mL} \mathrm{~min}^{-1}$. The method was validated according to the requirements of ANVISA within the range of $20-150 \mathrm{ng} \mathrm{mL}^{-1}(r>0.99)$. The LOD and LLOQ for fluazuron were 10 and $20 \mathrm{ng}$ $\mathrm{mL}^{-1}$ for plasma. The inter/intra-assay precision and accuracy were $\leq 9.48 \%(\mathrm{CV})$ and $\leq 10.3 \%$ (RSE) respectively. As results, the pharmacokinetic parameters Cmax $\left(74.4 \pm 3.52 \mathrm{ng} \mathrm{mL}^{-1}\right)$, AUCO-t $\left(1007 \pm 33.5 \mathrm{ng}^{*} \mathrm{~d} \mathrm{~mL}^{-1}\right)$ and t1/2 $(14.6 \pm 2.97 \mathrm{~d})$ for fluazuron after topical administration on cattle were obtained. The bioanalytical method was suitable for the application in pharmacokinetic studies, since LLOQ values for fluazuron allowed the quantification to reach $\mathrm{AUC}_{0-\mathrm{t}}$ greater than $80 \%$ of $A \cup C_{0-\infty}$.
\end{abstract}

Keywords: Benzoylphenylurea; bioanalytical method; sample preparation; pharmacokinetics.

\footnotetext{
* Universidade Federal Rural do Rio de Janeiro, Instituto de Ciências Biológicas e da Saúde, Departamento de Ciências Farmacêuticas, BR 465, km 7, CEP 23897-000, Seropédica, RJ, Brazil.

Myaracid@yahoo.com.br DOI: $10.21577 / 1984-6835.20190072$
} 


\section{Bioanalytical Method to Measure Fluazuron in Bovine Plasma and its Application in Pharmacokinetic Studies}

\section{Thais P. Ferreira, ${ }^{a}$ Isabela P. Lima, ${ }^{a}$ Viviane de S. Magalhães, ${ }^{b}$ Barbara R. Avelar, ${ }^{\mathrm{b}}$ Gabriela F. Oliveira, ${ }^{\mathrm{b}}$ Fábio B. Scott, ${ }^{\mathrm{b}}$ Yara P. Cid ${ }^{\mathrm{c}, *}$}

a Universidade Federal Rural do Rio de Janeiro, Departamento de Química, BR 465, km 7, CEP 23897-000, Seropédica-RJ, Brazil.

b Universidade Federal Rural do Rio de Janeiro, Departamento de parasitologia Animal, Instituto de Veterinária, BR 465, km 7, CEP 23897-000, Seropédica-RJ, Brazil.

c Universidade Federal Rural do Rio de Janeiro, Departamento de Ciências Farmacêuticas, Instituto de Ciências Biológicas e da Saúde, BR 465, km 7, CEP 23897-000, Seropédica-RJ, Brazil.

*yaracid@yahoo.com.br

\section{Introduction}

\section{Experimental}

2.1. Chemicals and reagents

2.2. Chromatographic conditions

2.3. Calibrators and quality control samples

2.4. Sample preparation

2.5. Method validation

2.6. Application to pharmacokinetic studies

\section{Results and Discussion}

3.1. Sample preparation

3.2. Method validation

3.3. Application to pharmacokinetic studies

\section{Conclusions}

\section{Introduction}

Fluazuron is a benzoylphenylurea that is marketed for the control of cattle ticks. It stands out within its class for having greater efficacy against ticks. ${ }^{1}$ In recent years fluazuron has been used in Latin America, Australia and South Africa in the strategic control of Rhipicephalus (Boophilus) microplus. ${ }^{2}$ Its mechanism of action differs from the majority of acaricides by not acting on the nervous system. Instead, it prevents ecdysis, interfering in the evolutionary cycle 
and reproduction of the tick, besides impairing egg hatching. ${ }^{3}$
The chemical structures of fluazuron and clorfluazuron (internal standard) are given in Figure 1.<smiles>O=C(NC(=O)c1c(F)cccc1F)Nc1ccc(Cl)c(Oc2ncc(C(F)(F)F)cc2Cl)c1</smiles>

A<smiles>O=C(NC(=O)c1c(F)cccc1F)Nc1cc(Cl)c(Oc2ncc(C(F)(F)F)cc2Cl)c(Cl)c1</smiles>

Figure 1. Chemical structure of fluazuron (A) and internal standard clorfluazuron (B)

Despite the lack of an official method for quantification of fluazuron, some authors have reported methods for quantification of the drug in different matrices: tissues, ${ }^{4-6}$ serum, 7 tea, 8 vegetables 9 and pharmaceutical formulations, ${ }^{10}$ involving liquid chromatography (LC) combined with ultraviolet detection (UV), Fourier-transform infrared spectroscopy (FTIR) and/or tandem mass (MS/MS) detection. In these methods, the sample preparation is by solid-liquid extraction, ${ }^{6,9}$ ultrasound assisted solid-liquid extraction, ${ }^{4,8}$ and salting out solid-liquid extraction. ${ }^{5}$

The determination of fluazuron in biological matrices (serum, plasma, blood) is useful to monitor drug concentration and provide basic information about its bioavailability in pharmacokinetic studies. Although pharmacokinetic evaluations of fluazuron in different animals ${ }^{7,11-13}$ have been reported, the number of papers describing specific details of the analytical procedure, such as lower limit of quantification (LLOQ), quantification range and method validation, is small. ${ }^{7,11,12}$
The aim of this study was to develop a costefficient bioanalytical method for pharmacokinetic evaluation of fluazuron in cattle. The experimental conditions were optimized by comparative study of three extraction methods: LLE, SPE and MSPD and the method validation were performed to meet the regulations of Brazil's National Sanitary Surveillance Agency (ANVISA). ${ }^{14}$ The developed and validated method was applied to a pharmacokinetic study after topical administration (pour-on) of fluazuron to cattle.

\section{Experimental}

\subsection{Chemicals and reagents}

LC grade solvents acetonitrile, dichloromethane, hexane and methanol were purchased from Sigma (St. Louis, USA). Diethyl ether and ethyl acetate were purchased from Tedia (Rio de Janeiro, Brazil). Fluazuron (99.1 
\%) and chlorfluazuron (97.9 \%) were purchased from Sigma-Aldrich (St. Louis, USA).

\subsection{Chromatographic conditions}

The LC-UV system consisted of a Dionex Ultimate 3000 system separation module coupled to a Dionex Ultimate 3000 UV-Vis detector (California, USA). The chromatographic separation was performed using a Kromasil C18 column (100 $\AA, 5 \mu \mathrm{m}$, 4.6x $250 \mathrm{~mm}$ ) (Tedia, Rio de Janeiro, Brazil) preceded by a Kromasil C18 guard column

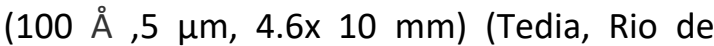
Janeiro, Brazil), both maintained at $25^{\circ} \mathrm{C}$. The mobile phase consisted of acetonitrile: water

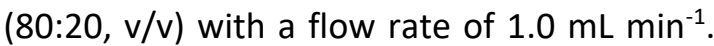
The UV wavelength was set at $260 \mathrm{~nm}$ and the injection volume was $10 \mu \mathrm{L}$. The LC-UV system was controlled by the Chromeleon 6.8 software from Dionex (California, USA).

\subsection{Calibrators and quality control samples}

The use of animals in this experimental was approved by the Ethics Committee on Animal Use of the Veterinary Institute of Rio de Janeiro Federal Rural University (CEUA-UFRRJ, protocol no. 4689260416).

Blood samples from the cattle were collected in heparinized tubes by jugular venipuncture. The collected blood samples were centrifuged at $756 \mathrm{~g}$ for $10 \mathrm{~min}$ at $4{ }^{\circ} \mathrm{C}$. Plasma samples used for spiking and blank studies were taken from experimental animals that were free of pesticides. Calibration standards were prepared by spiking the stock solutions in blank plasma to get final concentration series of 20,50,70,100, 120 and $150 \mathrm{ng} \mathrm{mL}^{-1}$. Quality control (QC) samples, including LLOQ (20 $\left.\mathrm{ng} \mathrm{mL}^{-1}\right)$, low (50 $\mathrm{ng} \mathrm{mL}^{-1}$ ), middle (70 $\mathrm{ng} \mathrm{mL}^{-1}$ ) and high (120 $\mathrm{ng} \mathrm{mL}^{-1}$ ) concentrations and upper limit of quantitation (ULOQ) (150 $\mathrm{ng} \mathrm{mL}^{-1}$ ) of standards were also prepared following the same procedure as for the calibration standards. Chlorfluazuron (IS) was added to all plasma samples at a concentration of $70 \mathrm{ng} \mathrm{mL}^{-1}$. Spiked plasma samples were transferred directly into $2 \mathrm{~mL}$ Eppendorf tubes and stored at the study site in a freezer at $-20^{\circ} \mathrm{C}$ until analysis.

\subsection{Sample preparation}

\subsubsection{Liquid-liquid extraction}

Four types of solvents were evaluated for the extraction procedure (ethyl acetate, dichloromethane, hexane, diethyl ether and hexane). One milliliter of each solvent was added to the plasma samples $(1 \mathrm{~mL})$, and the mixture was put in a rotary shaker for 1 minute. After centrifugation for 15 min at 756 $x \mathrm{~g}$, the supernatant was transferred to a vial and evaporated to dryness under heating (35 ${ }^{\circ} \mathrm{C}$ ) and resuspended in $500 \mu \mathrm{L}$ of acetonitrile for direct injection into the LC column.

\subsubsection{Solid phase extraction}

Solid phase extraction columns ( $3 \mathrm{~mL}, 500$ mg, DSC-18LT Discovery ${ }^{\circledR}$ ) from Sigma-Aldrich (St. Louis, USA) were placed in a Visiprep vacuum elution manifold from Sigma-Aldrich (St. Louis, USA). The cartridges were conditioned with $2 \mathrm{~mL}$ of methanol and $2 \mathrm{ml}$ of water, and then were loaded with the plasma samples $(1 \mathrm{~mL})$, washed with water (1 $\mathrm{mL}$ ) and then eluted with $1 \mathrm{~mL}$ of eluent (ethyl acetate, acetonitrile, dichloromethane, ether or hexane). Eluates were collected in vials, then evaporated to dryness under heating (35 ${ }^{\circ} \mathrm{C}$ ) and resuspended in $500 \mu \mathrm{L}$ of acetonitrile for direct injection into the LC column. 
2.4.3. Matrix solid phase dispersion extraction

The eluent that performed best in the SPE extraction was selected for MSPD procedures. The initial method was based on the work of Maffei (2009), ${ }^{15}$ where the sample: adsorbent and sample: drying agent mixture ratios used were 1:4. Briefly, spiked plasma samples $(0.125 \mathrm{~mL})$ were macerated with $\mathrm{C}_{18}$ adsorbent $(0.5 \mathrm{~g})$ and $\mathrm{Mg}_{2} \mathrm{SO}_{4}(0.5 \mathrm{~g})$ by grinding with a pestle for 2 minutes to produce a homogenous packing material. The blends were packed into a $3 \mathrm{~mL}$ SPE cartridge. The column was eluted with $1 \mathrm{~mL}$ of ethyl acetate and the fraction eluted was collected in a vial. The eluate was evaporated to dryness under heating $\left(35^{\circ} \mathrm{C}\right)$ and resuspended in 500 $\mu \mathrm{L}$ of acetonitrile for direct injection into the LC column.

Two parameters affect MSPD extraction, mixture ratio (sample: adsorbent) and cleanup step, were studied in order to optimize the extraction method. For cleanup step optimization, variable proportions of florisil $(0,125,250$ and $500 \mathrm{mg})$ pre-activated with acetonitrile were tested. Experiments using water as an alternative in the cleaning step were also performed. Different sample: adsorbent mixture ratios (1:2;1:3 and 1:4) were tested in order to evaluate the influence of mixture ratio on analyte recovery.

\section{LLE}

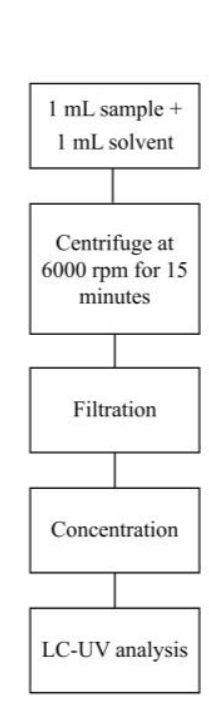

SPE

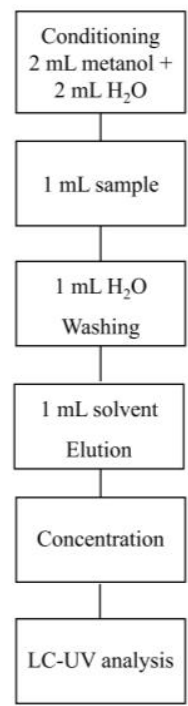

\section{MSPD}

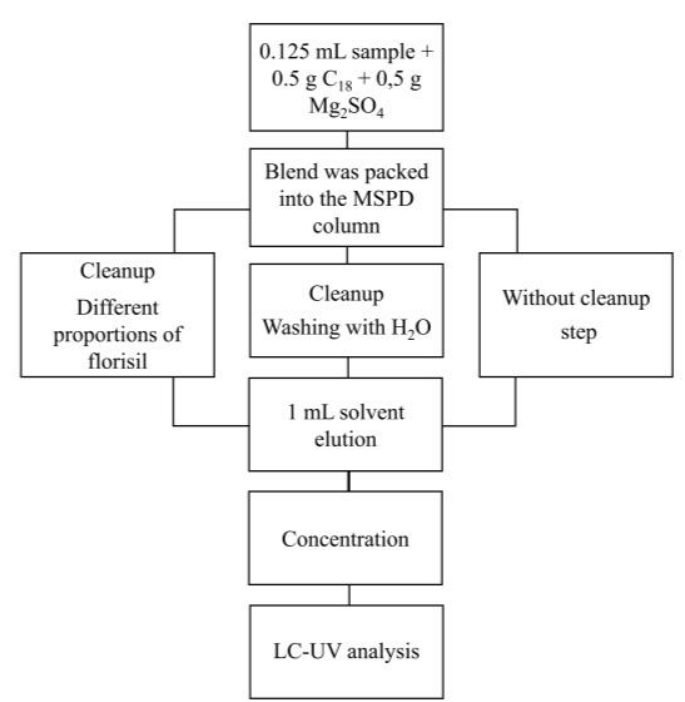

Figure 2. Comparison of sample preparation methods LLE, SPE and MSPD for fluazuron determination in bovine plasma

\subsection{Method validation}

The proposed method was validated using blank plasma and plasma spiked samples at different concentrations, in agreement with ANVISA guidelines. ${ }^{14}$
2.5.1. Limit of detection and limit of quantitation

The limit of detection (LOD) and limit of quantitation (LOQ) were determined at signalto-noise ratios of 3 and 10 , respectively, measured at the approximate retention time of the corresponding analyte peak. 


\subsubsection{Selectivity}

Selectivity was proven by using at least six individual sources of the blank plasma samples (four normal, one lipemic and one hemolyzed). These sources were individually analyzed and evaluated for interference. Interfering components were considered to be absent when the response was less than 20 $\%$ of the LLOQ for the analyte and $5 \%$ for the internal standard (IS).

\subsubsection{Matrix effects}

Matrix effects were investigated by analyzing eight samples from distinct sources (four normal, two lipemic and two hemolyzed) at two concentrations. The matrix factor (MF) was calculated for each sample. The ratio of the peak area in the presence of the matrix (measured by analyzing the spiked blank matrix after extraction) to the peak area in the absence of the matrix (pure solution of the analyte) was determined. IS-normalized MF should also be calculated by dividing the MF of the analyte by the MF of the IS. The CV of the IS-normalized MF calculated from all samples should not be greater than $15 \%$. This determination $(n=8)$ was conducted at LLOQ and ULOQ concentrations.

\subsubsection{Linearity}

The linear ranges of the method were evaluated as follows: $20-150 \mathrm{ng} \mathrm{mL-1}$ for fluazuron and $70 \mathrm{ng} \mathrm{mL-1}$ for IS. Calibration curves were generated by plotting the relative peak areas (analyte-to-IS) as a function of the plasma sample concentration on three consecutive days and three replicates for each concentration. Calibration standards were approved when the coefficient of variation (CV) was lower than or equal to $20 \%$ relative to the nominal concentration for the LLOQ, and lower than or equal to $15 \%$ relative to the nominal concentration of the other calibration standards.

\subsubsection{Precision and accuracy}

The precision and accuracy were determined from assays conducted on the same day (intra-assays) and on three consecutive days (inter-assays), by analyzing five samples per level of concentrations: LLOQ, low QC, medium $Q C$ and high QC, Precision was expressed as $\mathrm{CV}$ values that should not exceed $20 \%$ for LLOQ sample and $15 \%$ for the other QC samples. Accuracy, expressed as the relative standard error (RSE\%), should be within $15 \%$ of the nominal values for the $Q C$ samples. The exception is the LLOQ, which should be within $20 \%$ of the nominal value.

\subsubsection{Carryover}

The residual effect was assessed by injecting three aliquots of the same blank plasma sample: one before and two after analysis of the plasma sample spiked with the analyte at ULOQ concentration. Carryover in the blank sample following the high concentration standard should not be greater than $20 \%$ of the LLOQ and $5 \%$ for the in IS.

\subsubsection{Stability}

Stability of the analyte in plasma samples was evaluated under different conditions. Plasma samples $(n=5)$ at two QC levels (low and high) were subjected to short-term room temperature storage $\left(25{ }^{\circ} \mathrm{C}\right.$ for $\left.24 \mathrm{~h}\right)$, longterm storage $\left(-20{ }^{\circ} \mathrm{C}\right.$ for three months) and freeze-thaw cycles (three cycles of storage at $-20{ }^{\circ} \mathrm{C}$ for $24 \mathrm{~h}$ and thawing at room temperature) before sample preparation procedures and analysis. Post-preparative stability was also evaluated by analyzing processed samples after $24 \mathrm{~h}$ at room 
temperature. The results were compared with those of freshly prepared QC samples.

\subsection{Application to pharmacokinetic study}

The developed method was applied to fluazuron treatment of three red Angus cattle with a weight between 357 and $448 \mathrm{~kg}$. A dose of $2.5 \mathrm{mg} \mathrm{kg}^{-1}$ body weight (b.w.) of a topical commercial formulation of fluazuron $\left(\right.$ Acatack $^{\circledR}$ ) was administrated and blood was collected in heparin tubes by jugular venipuncture before and at $1,2,3,7,14,21$ and 28 days after treatment.

Plasma was obtained by centrifugation at $756 \times \mathrm{g}$ for $10 \mathrm{~min}$ at $4{ }^{\circ} \mathrm{C}$ and was stored at $20{ }^{\circ} \mathrm{C}$ until analysis. Sample extraction was carried out as described previously. The animal procedures were conducted in accordance with accepted standards for good clinical practice from the European Medicines Agency. ${ }^{16}$

\subsection{Data analysis}

Statistical analyses were performed using Microsoft excel and Minitab 16.2.4 (Minitab Inc., State College, PA, USA). The results obtained by applying the sample preparation procedures were compared statistically using analysis of variance (single factor ANOVA) and the Tukey test ${ }^{17}$ at $95 \%$ confidence. The residual plots of each day of analysis were examined for obvious patterns and Grubb's test ${ }^{18}$ was applied sequentially, until no further outliers were detected. The calibration curve was submitted to the Snecodor F-test ${ }^{17}$ to evaluate the homogeneity of residual variances. The weighted linear regression parameters ( $a$ and $b$ ) were obtained by the Minitab program. The calculation of $\Sigma$ EPR\% was performed by Microsoft excel from these parameters, to choose the most appropriate calibration model. The pharmacokinetic analyses were performed by Microsoft excel add-in program PK solver 2.3.

\section{Results and Discussion}

\subsection{Sample preparation}

LLE with different solvents (hexane, dichloromethane and ether) showed no selectivity. The LLE chromatograms with ethyl acetate (Figure 3 ) demonstrated that the extract obtained was unclean, requiring greater time for elimination of all interfering substances, thus generating higher cost and environmental impact by the use of large volumes of organic solvents. On the other hand, SPE and MSPD extraction demonstrated selectivity, as can be seen in the chromatograms using ethyl acetate as eluent (Figure 3).

Table 1 presents the results for recovery and precision obtained after the extraction of fluazuron by different procedures. Statistical analysis was performed only for results that met the requirements for recovery (80-120 \%) and precision (\% CV $\leq 15)$. 

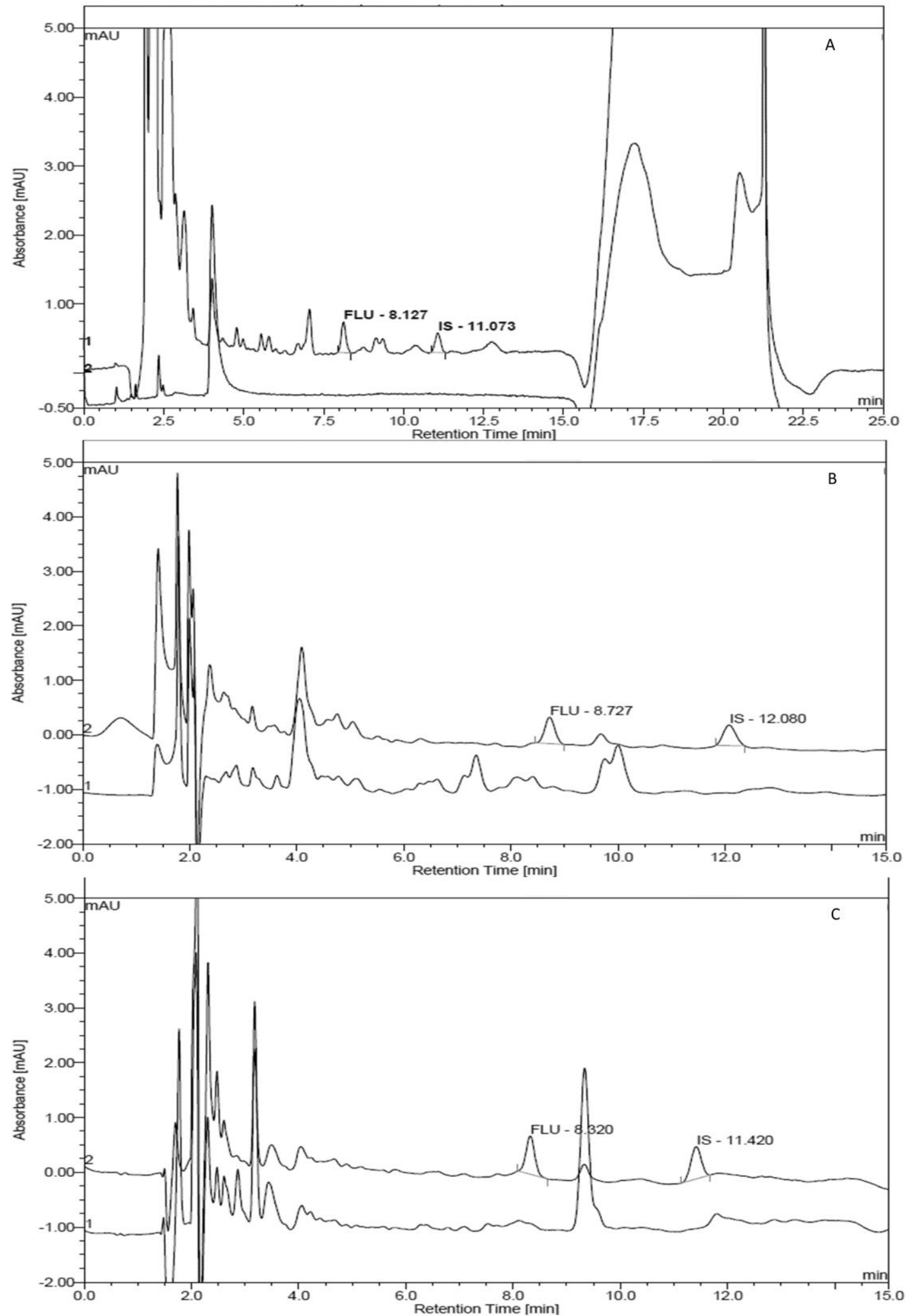

Figure 3. Chromatograms of blank and fortified ( $70 \mathrm{ng} \mathrm{mL}^{-1} \mathrm{FLU}$ ) plasma samples after liquidliquid extraction (A), matrix solid phase dispersion (B) and solid phase extraction (C) 
Table 1. Mean recovery (\%) and precision (\% CV) obtained by LC/UV after the extraction of fluazuron by different procedures $(n=5)$

\begin{tabular}{ccccccc}
\hline & \multicolumn{3}{c}{ Means recovery (\%) } & \multicolumn{3}{c}{ Precision (\% CV) } \\
\hline Solvent & LLE & SPE & MSPD* & LLE & SPE & MSPD \\
Acetonitrile & - & $130 \mathrm{a}$ & - & - & 23.6 & - \\
Ethyl acetate & $162 \mathrm{a}$ & $113 \mathrm{~b}$ & $109 \mathrm{~b}$ & 32.3 & 10.3 & 14.4 \\
Dichloromethane & $143 \mathrm{a}$ & $112 \mathrm{~b}$ & - & 23.5 & 9.19 & - \\
Ether & $153 \mathrm{a}$ & $88.5 \mathrm{c}$ & - & 30.9 & 12.5 & - \\
Hexane & $132 \mathrm{a}$ & $57.8 \mathrm{~d}$ & - & 30.1 & 14.4 & - \\
\hline
\end{tabular}

* Optimized method data

Data were statistically analyzed by one-way ANOVA (followed by Tukey's multiple comparison test). The level of significance was set at $p<0.05$.

Means in the row identified by different letters are statistically significant $(p<0.05)$

LLE with different solvents presented unsatisfactory recovery and precision results. The solid phase extraction showed a linear relation between the polarity of the eluent and recovery of the analyte from the adsorbent, which was expected since separation processes involving nonpolar analytes retained in nonpolar solid phases should be eluted by solvent with low dielectric constant $(\varepsilon) .{ }^{19}$ Achieving better results with low-polarity solvents such as hexane was not expected since the solubility of fluazuron in hexane is low in comparison with other more polar organic solvents. Ethyl acetate, dichloromethane and ether presented adequate extraction efficiency (80-120\%) and precision (0-15\%), within the acceptance range for bioanalytical methods, and can therefore be used as eluents in SPE. Due to the toxicity of dichloromethane and lower fluazuron recovery value from ether elution, ethyl acetate was chosen as eluent for the SPE and MSPD procedures.

The optimization of the cleanup step of the MSPD procedure demonstrated that the use of florisil as adsorbent led to a large reduction in the recovery percentage of the IS, directly influencing the extraction efficiency. The results suggest that an increase in the amount of florisil leads to greater adsorption of the active principles due to the increase of the contact surface, consequently reducing the extraction efficiency. The same was observed with the utilization of water in the cleanup step. Therefore, the cleanup step was eliminated from the extraction process.

Tests were performed to establish the ideal ratio between sample and adsorbent, which would provide a higher percentage of fluazuron extraction from plasma. The results of recovery (\%) and precision (\% CV) obtained with the proportions studied between sample: adsorbent were 125 and $6.0 \%, 117$ and $5.97 \%$ and 109 and $6.69 \%$ for ratios 1: 2; 1: 3 and 1: 4 respectively. The ratio $1: 4$ showed the best extraction efficiency, with an increase in the amount of adsorbent causing greater extraction efficiency of fluazuron. According to the literature, typically the amount of sample should be 4 times smaller than the amount of adsorbent so that the mixture is powdery and non-pasty, allowing better penetration of the eluent into the material. ${ }^{15}$

Despite the advantages of the MSPD technique related to the lower volume of sample and smaller consumption of organic solvent, the greater number of steps in the preparation of the sample, resulting in more time spent compared with the SPE technique, poses an obstacle to routine analyses, such as bioavailability studies, where a large number of samples need to be processed. Therefore, 
the SPE technique was chosen for validation of the method.

\subsection{Method validation}

The results showed that the method is selective, because responses from interfering peaks were close to the retention time of the analyte at $7.49 \%$, and showed no response or interfering response in the retention time of the IS.

The method's residual effect showed carryover from the blank samples following the ULOQ analysis not higher than $20 \%$ of the analytes' signal for the LLOQ, and $5 \%$ for the IS.

The CV of the IS-normalized MF (matrix effects) calculated from the eight samples was not greater than $15 \%(10.0 \%)$ as shown in Table 2.

Table 2. Summary of linearity, matrix effect, accuracy and precision data

\begin{tabular}{|c|c|c|c|c|c|c|c|c|}
\hline \multirow[t]{2}{*}{$\begin{array}{l}\text { Amount spiked } \\
\qquad\left(\mathrm{ng} \mathrm{mL}^{-1} \text { ) }\right.\end{array}$} & \multicolumn{3}{|c|}{ Linearity } & \multirow[t]{2}{*}{$\begin{array}{c}\begin{array}{c}\text { Matrix } \\
\text { effect }\end{array} \\
(\% \mathrm{CV}) \\
\mathrm{n}=8\end{array}$} & \multicolumn{2}{|c|}{$\begin{array}{c}\text { Accuracy } \\
\text { (\%RSE) } \\
n=5\end{array}$} & \multicolumn{2}{|c|}{$\begin{array}{c}\text { Precision } \\
\qquad \begin{array}{c}(\% C V) \\
n=5\end{array}\end{array}$} \\
\hline & Day 1 & Day 2 & Day 3 & & Intra-assay & Inter-assay & Intra-assay & Inter-assay \\
\hline 20 (LLOQ) & 5.23 & 13.3 & 6.74 & ND & 13.4 & -0.948 & 11.2 & 18.4 \\
\hline 50 (Low QC) & 4.59 & 3.75 & 3.68 & 3.79 & 10.3 & 6.76 & 7.45 & 9.11 \\
\hline 70 (Medium QC) & 7.40 & 6.73 & 7.96 & ND & 9.8 & -6.64 & 8.18 & 9.48 \\
\hline 100 & 3.97 & 1.83 & 3.43 & ND & ND & ND & ND & ND \\
\hline 120 (High QC) & 3.47 & 4.21 & 5.49 & 10.0 & 4.37 & 0.115 & 7.94 & 8.48 \\
\hline 150 (ULOQ) & 1.00 & 3.98 & 1.30 & ND & ND & ND & ND & ND \\
\hline
\end{tabular}

$\mathrm{ND}=$ parameters not determined

The calibration curves of fluazuron were prepared to determine the linearity of the method over the range of $20-150 \mathrm{ng} \mathrm{mL}^{-1}$. Integrated peak areas were plotted against analyte concentration, and linear regression was performed by the least-squares method. Calibration data presented heteroscedasticity, so the calibration curves were subjected to weighted linear regression analysis using $1 / \mathrm{V} x$ as the weighting factor. The calibration curve generated ( $y=0.00876 x+0.0399)$ using plasma as matrix showed a squared correlation coefficient of $>0.990$ for three days. The coefficient of variation (CV) was lower than $20 \%(5.23-13.3 \%)$ relative to the nominal concentration for the LLOQ, and lower than $15 \%$ (1.00-7.96 \%) relative to the nominal concentration of the other calibration standards.

The intra- and inter-assay accuracy evaluated for low QC, medium QC and high QC presented RSE values ranging from 4.37 to $10.3 \%$ (intra-assay) and from -6.64 to $6.76 \%$, (inter-assay). The intra- and inter-assay precision presented $\mathrm{CV}$ values ranging from 7.45 to $8.18 \%$ and from 8.48 to $9.48 \%$ respectively. The limit of detection (LOD) and limit of quantitation (LOQ) determined at signal-to-noise ratios of 3 and 10 was 10 and $20 \mathrm{ng} \mathrm{mL}^{-1}$. The LLOQ values corresponded to the lowest concentration of the calibration curves that could be measured with 
acceptable accuracy and precision (CV values lower than 20 \%) (Table 2).

The stability of spiked bovine plasma samples showed results within acceptable limits for all conditions tested, meaning that the samples were stable after storage and during sample preparation procedures. The accuracy values for fluazuron at both QC levels in all stability studies ranged from 91 to $108 \%$ and the $\% \mathrm{CV}$ were within $15 \%$. Fluazuron was stable in plasma samples at room temperature after $24 \mathrm{~h}$ of storage. Samples frozen at $-20 \circ \mathrm{C}$ remained stable for a minimum period of 3 months and after three freeze-thaw cycles. Also, post-preparative stability indicated that processed plasma samples can be stored in the autosampler up to $24 \mathrm{~h}$.

\subsection{Application to pharmacokinetic study}

The developed and validated method was successfully applied to the pharmacokinetic evaluation of fluazuron in cattle following topical (pour-on) administration of Acatack $^{\circledR}$ at a dose of $2.5 \mathrm{mg} \mathrm{kg}^{-1}$ body weight (b.w.). The plot of the mean fluazuron plasma concentrations as a function of time is shown in Figure 4.

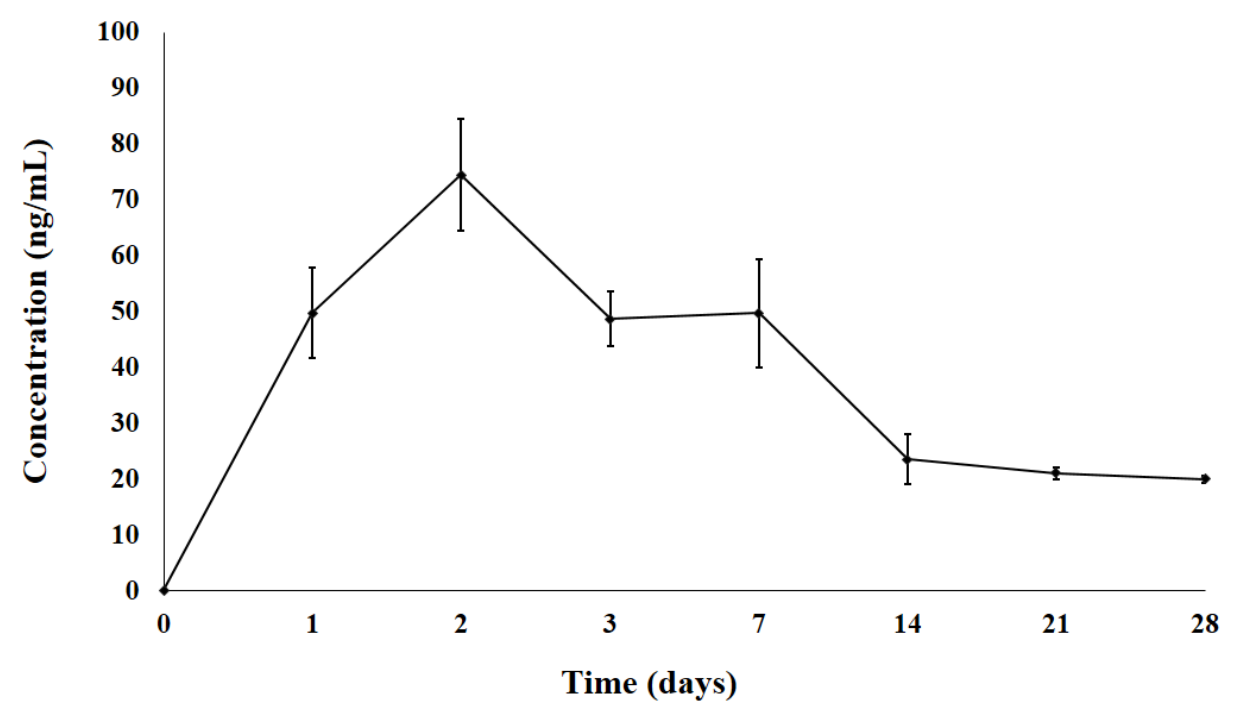

Figure 4. Plasma concentration curve of fluazuron versus time after administration of a dose of $2.5 \mathrm{mg} \mathrm{kg}^{-1}$ body weight of commercial pour-on formulation of fluazuron

The mathematical model used in The drug had a maximum plasma pharmacokinetics was non- concentration (Cmax) of $74.4 \pm 3.52 \mathrm{ng} \mathrm{mL}^{-1} 2$ compartmentalized from extravascular days $\left(T_{\max }\right)$ after treatment and the $t_{1 / 2}$ was 15 administration using the Microsoft Excel days, demonstrating rapid absorption and macro PK Solver. The pharmacokinetic slow elimination. parameters of fluazuron are listed in Table 3. 
Table 3. Pharmacokinetic parameters for fluazuron in cattle plasma $(n=3)$ after administration of a dose of $2.5 \mathrm{mg} \mathrm{kg}^{-1}$ body weight of a commercial pour-on formulation of fluazuron

\begin{tabular}{ccc}
\hline Compound & Parameter & $\begin{array}{c}\text { Value } \\
\text { (Mean } \pm \text { SD) }\end{array}$ \\
\hline \multirow{3}{*}{ Fluazuron } & $\mathrm{C}_{\max }\left(\mathrm{ng} \mathrm{mL}^{-1}\right)$ & $74.4 \pm 3.52$ \\
& $\mathrm{~T}_{\max }($ days $)$ & $2.00 \pm 0.00$ \\
& $\mathrm{~T}_{1 / 2}($ days $)$ & $14.6 \pm 2.97$ \\
& $\mathrm{AUC}_{0-\mathrm{t}}\left(\mathrm{ng}^{*} \mathrm{~d} \mathrm{~mL}^{-1}\right)$ & $1007 \pm 33.5$ \\
& $\mathrm{AUC}_{0-\infty}\left(\mathrm{ng}^{*} \mathrm{~d} \mathrm{~mL}^{-1}\right)$ & $1234 \pm 79.0$ \\
\hline
\end{tabular}

The bioanalytical method was suitable for application in the pharmacokinetic studies, since LLOQ values for FLU $\left(20 \mathrm{ng} \mathrm{mL}^{-1}\right)$ allowed the quantification to reach $A \cup C_{0-t}$ greater than $80 \%$ of the $\mathrm{AUC}_{0-\infty}$, in accordance with recommendation of Brazilian regulations ${ }^{13}$ for the ideal establishment of pharmacokinetic parameters.

The values found are similar to those determined by the studies of Xin-lu et al. $(2013)^{7}$ and Lopes et al. (2017), ${ }^{12}$ and the pharmacokinetic results of fluazuron showed that the drug concentrations in blood and the main pharmacokinetic parameters after different doses and forms of administration were very similar.

\section{Conclusions}

A rapid and cost-efficient bioanalytical method by LC-UV detection for fluazuron determination in bovine plasma was evaluated and validated. The comparative study of three methods of extraction (LLE, SPE and MSPD) demonstrated that the SPE procedure, in addition to its simplicity and efficiency, has the advantage of less extraction time and better suitability for batches of samples. The method was validated according to ANVISA, ${ }^{14}$ demonstrating good accuracy, precision and selectivity for quantitative bioanalysis of fluazuron in cattle plasma. The method was successfully applied in the pharmacokinetic study of fluazuron following topical (pour-on) administration in cattle.

\section{Acknowledgments}

This study was supported by Fundação de Apoio à Pesquisa Tecnológica of Federal Rural University of Rio de Janeiro (FAPUR).

\section{References}

${ }^{1}$ Graf, J. F. The role of insect growth regulators in arthropod control. Parasitology Today 1993, 9, 474. [CrossRef] [PubMed]

${ }^{2}$ Bull, M. S.; Swindale, S.; Overend, D.; Mess, E. Supression of Boophilus microplus populations with fluazuron- an acarine growth regulator. Australian Veterinary Journal 1996, 74, 468. [CrossRef] [PubMed]

${ }^{3}$ Reck, J.; Klafke, G. M.; Webster, A.; Dall'Agnol, B.; Scheffer, R.; Souza, U. A.; Corassini V. B.; Vargas, R.; dos Santos, J.S.; Martins, J.R. First report of fluazuron resistance in Rhipicephalus microplus: A field tick population resistant to six classe of acaricides. Veterinary Parasitology 2014, 201, 128.[CrossRef] [PubMed] 
${ }^{4}$ Zhang, Y.; Lu, X.; Hu, C.; Cui, W.; Liu, X. Development of a high-performance liquid chromatography method for quantification of fluazuron in cattle tissues. Journal of Liquid Chromatography \& Related Technologie 2013, 36, 2559. [Link]

${ }^{5}$ Yamada, R.; Kozono, M.; Ohmori, T.; Morimatsu, F.; Kitayama, M.; Simultaneous determination of residual veterinary drugs in bovine, porcine, and chicken muscle using liquid chromatography coupled with electrospray ionization tandem mass spectrometry. Bioscience, Biotechnology, and Biochemistry 2006, 70, 54. [CrossRef] [PubMed]

${ }^{6}$ Armishaw, P.; Ward, J.; Millar, R. G. Development of a reference material for residues of chlorfluazuron and fluazuron in beef fat ACSL CRM 3. Fresenius Journal of Analytical Chemistry 1996, 356, 13. [CrossRef] [PubMed]

${ }^{7}$ Xin-Iun, L.; Yu-mei, Z.; Cheng-yun, H.; Weibo, C.; Xue, L.; Ming-rong, Z. Pharmacokinetics of fluazuron in cattle. Chinese Journal of Veterinary Science 2013, 10, 1595. [Link]

${ }^{8}$ Chen, L.; Chen, J. F.; Guo, Y.; Li, J.; Yang, Xu, L.; Fu, F. Study on the simultaneous determination of seven benzoylurea pesticides in Oolong tea and their leaching characteristics during infusing process by HPLC-MS/MS. Food Chemistry 2014, 143, 405. [CrossRef] [PubMed]

${ }^{9}$ Hui-ying, D.; Wen, X.; Zhao-qian, Z.; Bo, L.; Qin-ting, J. Determination of 11 Benzoylurea Insecticides Residues in Vegetable by LCMS/MS. Journal of Instrumental Analysis 2009, 8. [Link]

${ }^{10}$ Silva, M. S.; Gonring, K. L.; Silva, R. C. S.; Fonseca, M.C.; Borges, M. M. C.; Nunes, O. C.; Forim, M. R.; Borges, K. B.; Borges, W.S. Fourier transform infrared spectroscopy, thermogravimetric analysis, scanning electron microscopy as supporting tools in quality control of antiparasitics. Química Nova 2018, 41, 258. [CrossRef]
${ }^{11}$ Austin, C. M.; Dissertação de Mestrado, University of Pretoria, África do Sul, 2016. [Link]

12 Lopes, W. D. Z.; Chiummo, R. M.; Vettorato, L. F.; Rodrigues, D. C.; Sonada, R. B. The effectiveness of a fixed-dose combination pour-on formulation of $1.25 \%$ fipronil and $2.5 \%$ fluazuron against economically important ectoparasites and associated pharmacokinetics in cattle. Parasitology International 2017, 66, 627. [CrossRef] [PubMed]

${ }^{13}$ Pasay, C.; Rothwell, J.; Mounsey, K.; Kelly, A.; Hutchinson, B.; Miezler, A. An exploratory study to assess the activity of the acarine growth inhibitor, fluazuron, against Sarcoptes scabei infestation in pigs. Parasites \& Vectors 2012, 5, 40. [CrossRef] [PubMed]

${ }^{14}$ Agência Nacional de Vigilância Sanitária (ANVISA). Resolução-RDC N²7, de 17 de maio de 2012, Brasil, 2012.

${ }^{15}$ Maffei, D.; Rita, A.; Nogueira, A.; Helena, S.; Brondi, G. Determinação de resíduos de pesticidas em plasma bovino por cromatografia gasosa-espectrometria de massas. Química Nova 2009, 32, 1713. [CrossRef]

${ }^{16}$ European Medicines Agency (EMA); E 6 (R1) Guideline for Good Clinical Practice (CPMP/ICH/135/95), 1995, Note for guidance on Good Clinical Practice, June 14 2017, Londres, 2017.

${ }^{17}$ Vieira, S.; Análise de Variância (ANOVA), 1 a. ed., Atlas: São Paulo, 2006.

${ }^{18}$ Grubbs, F. E.; Beck, G. Extension of sample sizes and percentage points for signicance tests of outlying observations. Technometrics 1972, 14, 847.

${ }^{19}$ Queiroz, S. C. N; Collins, C. H.; Jardim, I. C. S. F. Métodos de extração e/ou concentração de compostos encontrados em fluidos biológicos para posterior determinação cromatográfica. Química Nova 2001, 24, 68. [CrossRef] [PubMed] 